\title{
O voo do cisne: quando o corpo testemunha a dança
}

The swan's flight: when the body testifies the dance Andréia Nhur (Andréia Vieira Abdelnur Camargo)

Andréia Nhur (Andréia Vieira Abdelnur Camargo) Professora do Departamento de Artes Cênicas da ECA-USP. Bailarina do grupo Pró-Posição e atriz do Grupo Katharsis Teatro.

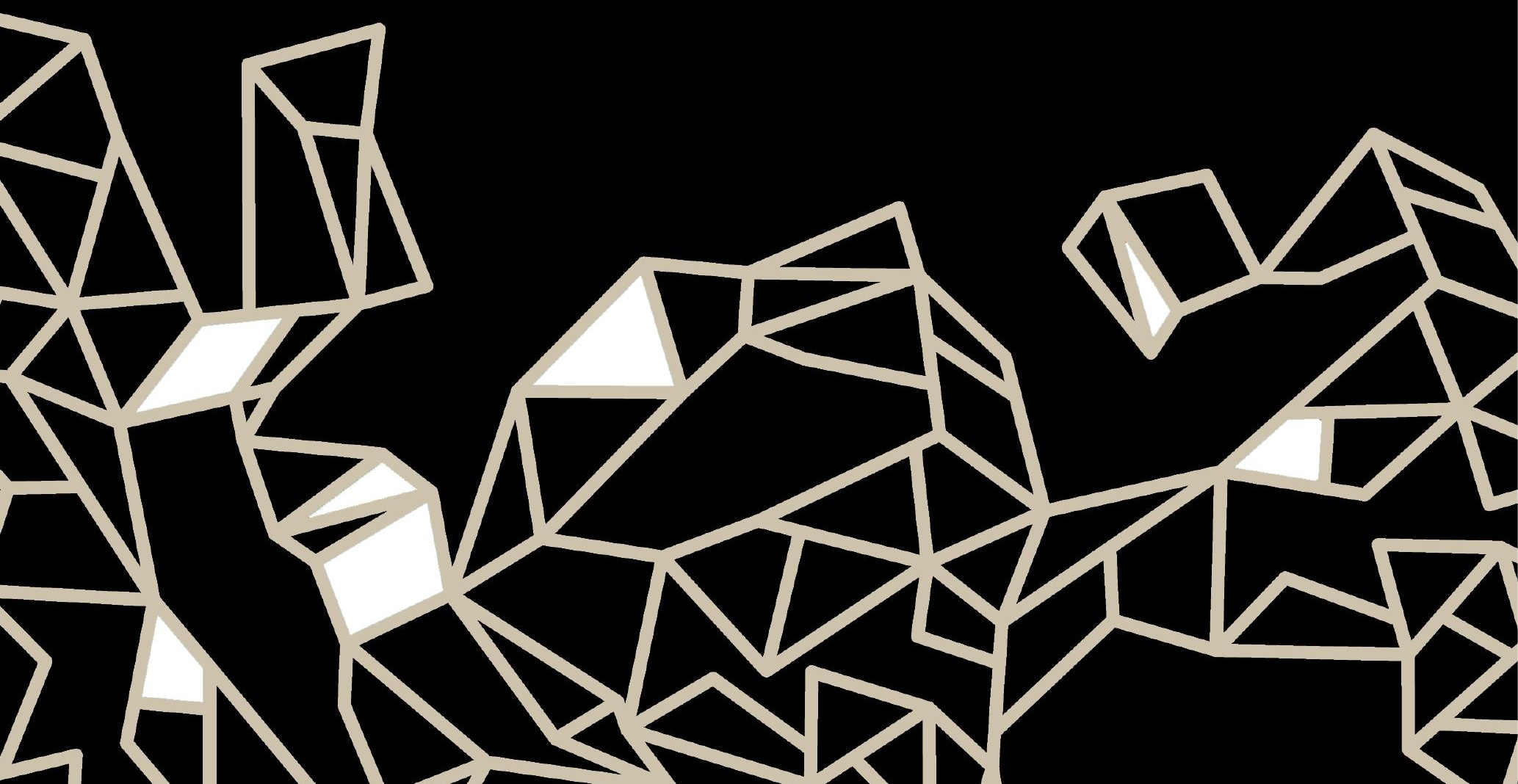




\section{Resumo}

Este artigo trama diferentes experiências de recriação coreográfica sobre a figura emblemática do cisne para discutir como o corpo pode ser visto como testemunho da dança e dos sujeitos que dançam ao longo dos séculos XIX, XX e XXI. O cisne, uma das figuras mais citadas pela gestualidade da dança ocidental, alvitra uma possibilidade de olhar as histórias da dança e compreender em que medida os corpos atravessaram as tradições e se impuseram como coautores daquilo que se convencionou chamar de História da Dança. Com base em Estudos do Corpo, Teoria e Historiografia da dança, aportaremos na análise da Trilogia do Cisne, obra coreográfica criada pelo grupo brasileiro Pró-Posição entre 2007 e 2009.

Palavras-chave: História da dança, Cisne, Corpo, Sujeito, Testemunho.

\section{Abstract}

Using different experiences of choreographic creation inspired by the swan, an emblematic figure in dance history, this article aims to discuss how the body can be seen as testimony of dance and the dancers during the 19th, 20th, and 21st centuries. The swan is one of the figures most frequently mentioned by the gestures of western dance, and as such it allows observing dance histories and comprehending how different bodies crossed traditions and imposed themselves as coauthors of Dance History (as it has been conventionally named). The theoretical fundaments are based on Body Studies, Dance Studies, and Dance Historiography. At the end, the article will analyze the choreographic pieces of Trilogy of Swan, created by the Brazilian artists of Pró-Posição Group between 2007 and 2009.

Keywords: Dance history, Swan, Body, Subject, Testimony.

\section{O cisne da dança clássica: rabiscos cronológicos}

O lago dos cisnes - cujo libreto foi escrito por Vladimir Begichev e Vasily Geltzer - é um balé mítico, de linhagem romântica. A obra conta a história de um príncipe, Siegfried, que deveria escolher uma noiva num baile anunciado pela rainha. Inserido na atmosfera romântica, Siegfried se apaixona por Odette, uma mulher transformada em cisne por um feiticeiro. Para quebrar o feitiço, 
o príncipe promete seu amor a Odette, mas, na noite do baile, confunde-a com Odile - a filha do feiticeiro, sósia de Odette -, o cisne negro (TESTA, 2008b).

Em 1877, na Rússia, Julius Wentsel Reisinger (1828-1892) coreografou a primeira versão de O lago dos cisnes, com música de Peter Ilyich Tchaikovsky (1840-1893), no Teatro Bolshoi de Moscou. Apesar de ter sido remontada e reencenada por Joseph Hansen (1842-1907), a obra só obteve sucesso com a versão do francês Marius Petipa (1818-1910) ${ }^{1}$ e do russo Lev Ivanov (1834-1901), em 1895 (BREMSER, 1993; TESTA, 2008b).

Nesse momento, a dança europeia vivia uma mudança de perspectiva, detonada por transições políticas e culturais que marcariam definitivamente a importância de $O$ lago dos cisnes na história da dança. Paris, em meio à queda do Segundo Império de Napoleão, perdia o status de capital da dança, ao passo que a Rússia se edificava como um novo centro (GINOT; MICHEL, 2008). É nesse contexto que Petipa, na posição de maître de ballet do Teatro Imperial Mariinsky, misturou o vocabulário coreográfico advindo da escola francesa às técnicas desenvolvidas pela escola italiana e inaugurou o academicismo, criando uma dança de alto apuro técnico e virtuosismo que preenchia as narrativas de contos de fadas de herança romântica (GINOT; MICHEL, 2008).

Entre dezenas de montagens e adaptações de $O$ lago dos cisnes, nos séculos XIX e XX, a que prevaleceu, em grande parte, foi a versão de Petipa e Ivanov. Sob o crivo de seus criadores, a obra manteve suas características principais, como a famosa coda do pas-de-deux entre o cisne negro e o príncipe, em que a bailarina executava 32 giros (fouettés). Com pequenas modificações, O lago dos cisnes foi (e continua sendo) reencenado inúmeras vezes por companhias de repertório mundo afora, adaptando corpos a uma estética demarcada pelo academicismo russo.

Entretanto, a recorrência de uma obra de dança, bem como de sua temática e corporeidade intrínsecas, não as torna imunes às variações que o tempo e os sujeitos Ihes impõem. Mesmo numa reencenação em que a reprodução dos movimentos e dos atos pretende ser fiel às formas anteriores, ditas

1 Marius Petipa foi primeiro bailarino em São Petersburgo (em 1847) e ficou a serviço do Balé Imperial russo até 1904, quando se aposentou. Como coreógrafo, deixou seu maior legado, ao recuperar o romantismo e elaborar a técnica da dança clássica (LE MOAL, 2008). 
"originais", há um processo de tradução inevitável, tributário das diferenças entre os sujeitos que dançam essa "mesma" dança.

A noção de sujeito aventada neste estudo conversa com uma série de autores que investigam a dimensão política da expressão física na dança. Em The work of dance: labor, movement, and identity in the 1930s, o pesquisador Mark Franko (2002) convoca o filósofo marxista Louis Althusser para propor que "sujeitos são constituídos de auto-reconhecimento no processo de percepção estética" (p. 59, tradução nossa). ${ }^{2}$ Em linhas gerais, a tese de Althusser defende que um indivíduo se constitui como sujeito por meio da interpelação ideológica, isto é, não há sujeito sem ideologia. Com isso, apreendemos que todo corpo que dança é sujeito de uma condição ideológica.

Em Next week, Swan Lake: reflections on dance and dances, a historiadora da dança Selma Jeanne Cohen (1982) aponta que não só os contextos de produção da dança de $O$ lago dos cisnes mudaram ao longo dos séculos, mas também os sujeitos implicados nas obras, ou seja, artistas e público. A versão de Fyodor Lopukhov (1886-1973), de 1945, por exemplo, forjava, devido à censura dos oficiais da União Soviética, um combate em que Siegfried arrancava as asas de Rothbart. Na versão anterior, de Petipa e Ivanov - a qual era aprovada com grande entusiasmo pelo Czar Nicholas II -, Siegfried e Odette morriam, coroando a vitória do amor e a maldição de Rothbart. Inserida em outro regime político, a versão de Lopukhov materializava o sucesso da revolução russa, em detrimento do extermínio do Czar, na figura do feiticeiro (COHEN, 1982).

Assim, pode-se dizer que o caráter transitório e subjetivado do processo de transmissibilidade na dança é a garantia de que uma obra nunca será reencenada da mesma forma. Embora possa manter resquícios de uma tradição, a recriação de uma peça terá de passar pela atualização em novos corpos e ambientes. E como corpo não é suporte, ele troca informações com o ambiente, modificando-se e modificando o ambiente.

Essa perspectiva de corpo foi notadamente formulada pela Teoria Corpomídia, das pesquisadoras brasileiras Christine Greiner e Helena Katz, no campo dos estudos do corpo. Para as autoras, o conceito de corpomídia não define corpo como processador de informações, mas como mídia de si mes-

2 No original: "Subjects are constituted by self-recognition in the process of aesthetic perception" (FRANKO, 2002, p. 59). 
mo, isto é, capaz de gerar informações próprias a partir de tudo aquilo com que entra em contato (GREINER, 2005; KATZ, 2005; 2008b; 2010).

Numa uma tentativa de reprise ou remontagem, vestígios de estruturas coreográficas do passado entram em fricção com um processo de atualização constante dos corpos-sujeitos implicados no agora. Desse modo, a transmissão seria uma tarefa impossível, já que corpos distintos nunca poderiam replicar a mesma informação, mas sim negociar com ela de acordo com sua singularidade.

\section{O cisne morto}

Para a pesquisadora francesa Isabelle Launay (2010), cujos estudos centram numa proposição inventiva da história da dança, a ideia de citabilidade - formulada por Walter Benjamin e revista por Hanna Arendt - deveria ser absorvida pelo campo da dança a fim de se compreender as dinâmicas de comunicabilidade entre obras, notações, transcrições, criadores e intérpretes de dança. Citando Benjamin, Launay afirma que a modernidade exigiu a descoberta de um estilo novo de relação com o passado, substituindo a transmissão do passado por uma citabilidade que poderia se instalar nos fragmentos do presente (LAUNAY, 2010).

Segundo Launay (2010), a citação no balé, embora recorrente e altamente intergestual, se dava em nome de uma tradição e da manutenção das instituições coreográficas, isto é, as companhias de balé e de repertório: "A citação clássica repousava sobre hierarquias e valores que, ainda que instáveis, serviam como medida para o julgamento sobre a adequação das variações. Ela ocorria, assim, em nome de uma tradição que o público conhecia" (LAUNAY, 2013, p. 91).

Todavia, o estilo novo de relação com o passado de que falava Benjamin nada teria a ver com manter uma tradição - mesmo que aberta a variações. Pelo contrário, sua afirmação pregaria a favor da impossibilidade da transmissão da tradição (LAUNAY, 2010).

É a partir dessa postura de citabilidade que o século $X X$ ganha atualizações livres da caução da tradição e permite não apenas versões com o selo "pós-Petipa e Ivanov", mas traduções e citações diversas do cisne. 
Em 1905, o coreógrafo Michel Fokine (1880-1942) ${ }^{3}$ criou A morte do cisne para a bailarina Anna Pavlova (1881-1931)4. Já num contexto completamente distinto de $\mathrm{O}$ lago dos cisnes, a obra de Fokine inaugurou, dentro da gramática da dança clássica, outras formas de mover, em que a expressividade punha-se à frente do virtuosismo.

De 1890 a 1914, uma nova estética se propagava na Europa, Rússia e EUA, relacionada à Art Nouveau e ao moderno estilo russo. Interessado por todas as formas de arte, Fokine se juntou ao coletivo que se formava em torno do empresário artístico Sergei Diaghilev (1872-1929), fundador do Ballets Russes. Em 1901, assistiu às primeiras apresentações do Teatro de Artes de Moscou, liderado por Constantin Stanislavski (1863-1938), e em 1904 entrou em contato com as ideias de Isadora Duncan (1877-1927), conhecida como precursora da dança moderna (LOT, 2007).

É sob esse contexto que Anna Pavlova, no início do século $X X$, pede ajuda a Fokine para compor um solo que seria apresentado numa gala de caridade. O jovem coreógrafo, que também tinha formação como músico, apropriou-se da partitura Cisne, retirada de O carnaval dos Animais de Camille Saint-Saëns (1835-1921), para compor um breve solo com um simples argumento: um cisne entraria em cena para morrer (ROSSÉ, 2000).

Essa versão, reiterada pela International Encyclopedia of Dance (1998) - em que Pavlova teria encomendado o solo a Fokine - marcaria já uma nova relação entre coreógrafo e intérprete, pois, até então, era comum um coreógrafo criar algo para uma grande estrela, mas não o caminho inverso (LOT, 2007).

A coreografia sem virtuosismo, com uma música que não havia sido escrita para ser dançada, misturada à expressividade e ao simbolismo adotados por Pavlova em sua interpretação - em que os braços livres traziam a incapacidade do cisne para se evadir do destino que o esperava -, colocava a obra numa plataforma distinta do que se fazia na dança russa até então (ROSSÉ, 2000).

3 Bailarino e coreógrafo russo, Fokine foi coreógrafo do repertório escolhido por S. Diaghilev quando do lançamento do Ballets Russes em Paris, em 1909. Recuperando alguns pontos de vista de Noverre, Fokine buscava maior expressividade em sua arte, contra o virtuosismo gratuito e a rotina de uma dança vazia e sem substância (GINOT; MICHEL, 2008).

4 Bailarina e coreógrafa russa, foi primeira bailarina do Mariinsky em 1906. Entre 1909 e 1911, dançou na companhia de S. Diaghilev e, em 1911, fundou sua própria companhia. Missionária do balé clássico, viajou com seus bailarinos por vários continentes (LE MOAL, 2008). 
O uso do peso da cabeça, dos braços e das mãos, a perda da verticalidade e a alternância entre tensão e relaxamento que se fazia visível no trabalho de respiração de Pavlova - cujo conjunto de contrações, convulsões e tomadas de fôlego organizava uma cena pulmonar - destronava estéticas basilares do balé clássico (LOT, 2007).

Tal transgressão ao vocabulário clássico era um alento para o movimento da dança moderna que se afirmaria com Rudolf Laban (1879-1958) na Alemanha do início do século XX. Em homenagem fúnebre a Pavlova, Laban teria destacado a capacidade da bailarina russa de diluir a rigidez da técnica clássica e ser o "instrumento perfeito e pronto ao movimento de ideais revolucionários propostos pelo jovem Fokine”5 (LABAN, 1931 apud LOT, 2007, p. 81, tradução nossa).

Mary Wigman (1886-1973), discípula de Laban e fundadora da Dança de Expressão (Ausdruckstanz), em carta aberta a Pavlova, escrita provavelmente em 1928, lançava um elogio paradoxal à bailarina russa, anunciando-a como estandarte do desaparecimento da linhagem clássica que vinha desde as grandes estrelas que marcaram a história do balé clássico mundial. Com um tom lúgubre diante daquela dança que ela mesma, Mary Wigman, queria derrocar, a carta é uma tentativa de enterrar, elogiosamente, Anna Pavlova e toda a tradição do balé que se vinculava a ela (LAUNAY, 1996):

Eu não vejo somente a última dançarina clássica lá embaixo; mas como uma visão, eu vejo toda uma linhagem de antepassados que a ajudaram a se constituir, os Taglioni, os Camargo e os Elssler. Eu vejo a evolução, o brilho, a estagnação, o declínio dessa arte frente à morte a que fomos convidados esta noite. Anna Pavlova, sabes que dançavas a morte, a mais bela morte que pode imaginar a fantasia humana? Tu, a última grande, tu, agora isolada no meio da pompa e alegria a teu redor! Como irradias, como esta morte te transfigura. Eu vejo a riqueza do passado atrás de ti, o luxo intelectual dos franceses, o luxo bárbaro da corte do Czar; eu vejo uma disciplina sem exemplo, a inflexibilidade da formação, a ambição, a agitação incessante. Não deves temer, Anna Pavlova, deves continuar a sorrir. Os séculos são mantidos em estado de alerta, eles te sustentarão segura em seus braços até o último passo de dança. (WIGMAN apud LAUNAY, 1996, p. 227) ${ }^{6}$

5 No original: "Elle étaitl'instrument parfait et prêt au mouvementd'idées révolutionnaires proposé par le jeune Fokine" (LABAN, 1931 apud LOT, 2007, p. 81).

6 "Je ne vois pas seulement la dernière grande danseuse classique, là-bas en bas; mais comme dans une vision, je vois toute une rangée d'ancêtres qui l'ont a idée à terminer, les Taglioni, les Camargo, 

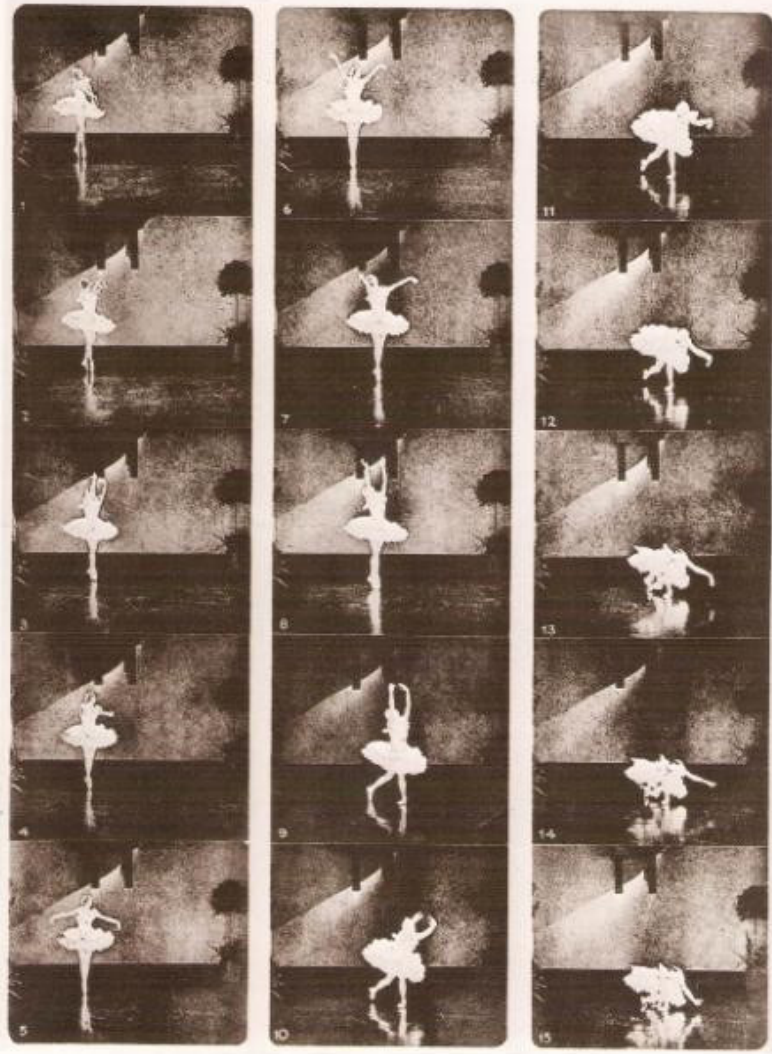

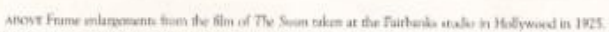

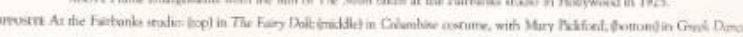

338

Figura 1 - Pavlova em A morte do cisne.

Hollywood, 1925. Foto: Money (1982, p. 338).

A presença autoral de Pavlova, nessa dança quase improvisada, demarca não só uma despedida fúnebre da tradição clássica, mas um testemunho diante de uma mudança de contexto. Mais do que um marco temporal de transição entre clássico e moderno - o que incorreria num historicismo desavisado -, A morte do Cisne de Pavlova e Fokine deu voz e visibilidade ao sujeito que dança.

les Essler. Je vois l'évolution, l'éclat, la stagnation, le déclin de cet art à la mort du quel nous sommes conviés ce soir. Anna Pavlova, sais-tu que tu dansais la mort, la plus belle mort que puísse imaginer la fantaisie humaine? Toi, la dernière grande, toi, à présenti solée au milieu du faste et de allégresse qui t'entourent! Comme tu rayonnes, comme cette mort te transfigure. Je vois la richesse du passé derrière toi, le luxe cultive des Français, le luxe barbare de la cour du Tsar; je vois une discipline sans exemple, l'inflexibilité de la formation, l'ambition, l'agitation incessante. Tu n'as pás besoin de t'effrayer, Anna Pavlova, tu dois continuer de sourire. Les siècles se tiennent em éveil, ils te porteront de leurs brás sûrs jusqu'au dernier pes de danse" (WIGMAN apud LAUNAY, 1996, p. 227). 
No decorrer do século XX e início do século XXI surgem diversas interpretações e referências ao cisne, não mais como índices de uma tradição insistente, mas como citações de corpos singulares, dedicados a testemunhar o passado nas reminiscências do presente. Em 1965, Maurice Béjart (19272007) coreografou Le Cygne, com música tradicional hindu, baseada no poema de Rabindranath Tagore (LÍVIO, 2004). Em 2005, Raimund Hoghe criou Swan Lake et Histoire de danse et 4 acts, versão solo com um bailarino masculino e com um fim apoteótico em que o cisne é sacrificado nu e coberto com talco (BOISSEAU, 2008). Em 2010, Mathilde Monnier concebeu Pavlova 3'23" para nove bailarinos, que encenam metáforas diversas sobre a morte do corpo, das ideologias e da história, catalisadas por um cisne que não é representado, imitado ou citado diretamente. Entre 2011 e 2012, o projeto SWAN, do coreógrafo francês Luc Petton, com cisnes de verdade, mostrava animais de patas desajeitadas, com pescoços longos e pernas curtas e desproporcionais, criando movimentações emergentes da relação entre o cisne e o humano.

\section{A Trilogia do Cisne e o corpo testemunho}

Em 2007, por ocasião de uma parceria inusitada, eu e minha mãe, Janice Vieira, ${ }^{7}$ resolvemos reativar o grupo Pró-Posição (fundado em 1973 e extinto em 1983) $)^{8}$ para fins de nomeação de nosso trabalho: uma série de espetáculos autobiográficos inspirados no cisne, a que, mais tarde, intitulamos Trilogia do Cisne.

7 Bailarina, coreógrafa, acordeonista e professora, Janice Vieira estudou com Maria Olenewa e Maria Duschenes (1922-2014) nos anos 1950 e 1960. Ao longo de sessenta anos de carreira, criou dezenas de espetáculos e formou inúmeros bailarinos. Sua trajetória foi contada no documentário Figuras da Dança: Janice Vieira (produzido pela São Paulo Cia. de Dança) e sua carreira na dança foi laureada pelo Prêmio Governador do Estado em 2013.

8 O Pró-Posição foi fundado no interior de São Paulo por Janice Vieira e Denilto Gomes (1951-1994). Marcante na história da dança do Brasil entre os anos 1970 e 1980, o grupo participou ativamente de movimentos como o Teatro de Dança Galpão e a Oficina Nacional de Dança Contemporânea da Bahia. Com uma postura ousada e engajada, sua produção se tornou referência em experiências de hibridação de linguagens (dança e teatro) dentro de uma estética tarjada pela passagem de seus integrantes pela escola de Maria Duschenes. Nos anos 2000, a parceria entre mãe e filha bailarinas reativou o nome do grupo, traçando uma pesquisa cênica documental em que trabalhos do passado - do repertório do grupo ou de seus integrantes - são citados ou rememorados nos corpos do presente. Esse contexto de investigação rendeu ao grupo o Prêmio da Associação Paulista de Críticos de Arte de Pesquisa em Dança, em 2013, concluindo uma linha de trabalhos a que nomeamos "dança documental", composta pela Trilogia do Cisne e por Vis-à-Vis (2012). 
A Trilogia é composta por Swan: corpo adaptado, O cisne, minha mãe e eu e LinhaGens, três obras que giram em torno de um mesmo eixo para conflitar herança e continuidade na dança, a partir da figura do cisne. $O$ fio que une os três trabalhos é uma carta com instruções para se dançar a coreografia A morte do cisne (de Pavlova e Fokine). A carta foi escrita pela bailarina e professora russa Maria Olenewa (1896-1965) à minha mãe, no fim dos anos 1950. Minha mãe foi aluna de Olenewa, que havia sido aluna e primeira bailarina da companhia de Anna Pavlova. No entanto, minha mãe nunca me ensinou a coreografia e, nos anos 2000 , entregou-me a carta para que eu decifrasse a meu modo.

O solo Swan: corpo adaptado - apresentado em 2007 no Festival Internacional Panorama de Dança (RJ) - brinca com a relação entre gene biológico e gene cultural para dialogar com o que resta da tradição clássica.

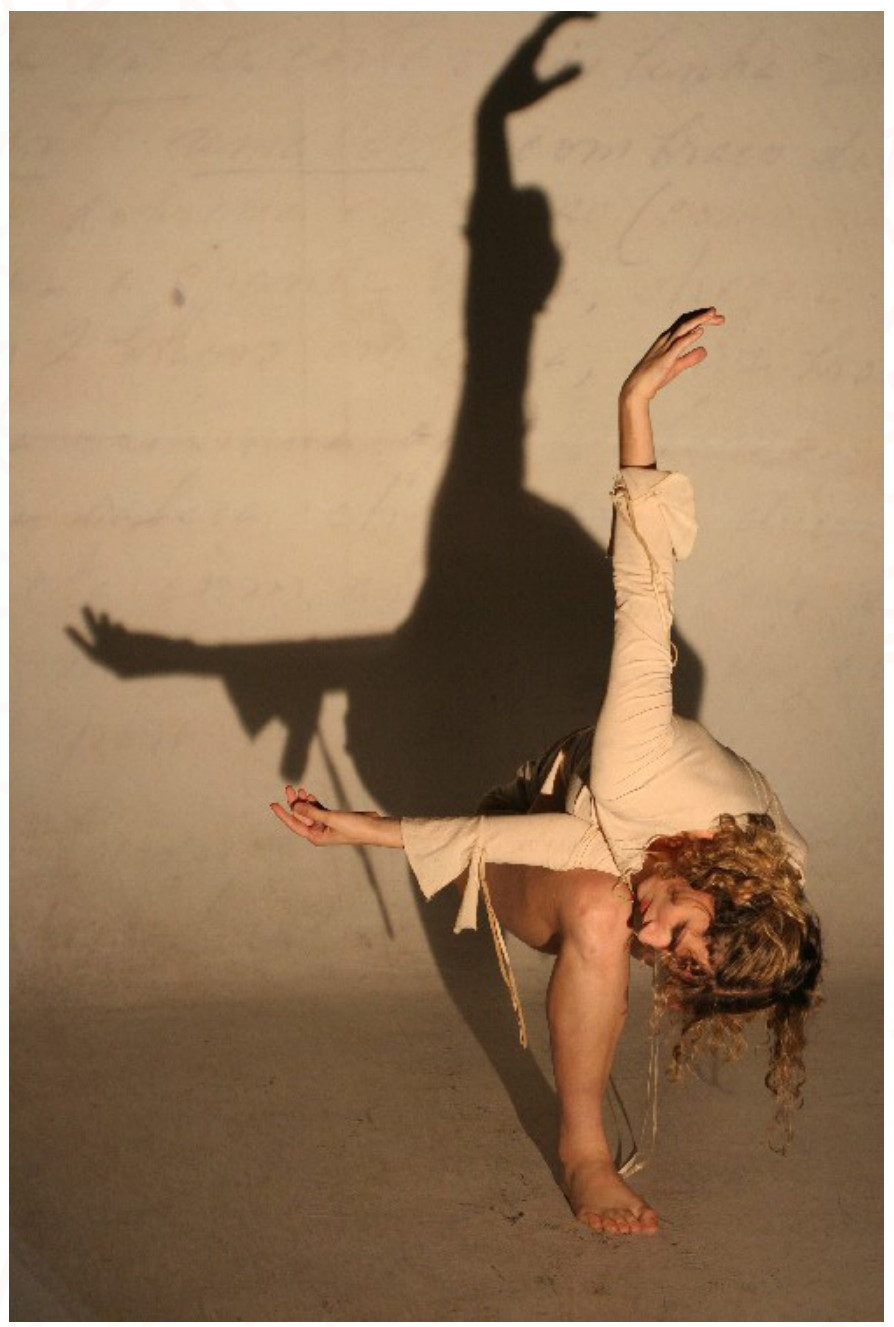

Figura 2 - Andréia Nhur em Swan: corpo adaptado (2007). Foto: José Neto. 
O cisne, minha mãe e eu (2008), apresentado no Festival Contemporâneo de Dança (SP), reúne mãe e filha em cena, usando o relato e a biografia narrada:

O cisne, minha mãe e eu, de e com Janice Vieira e Andréia Nhur, talvez seja uma das mais competentes demonstrações já realizadas de como tratar a questão do legado em dança. Um verdadeiro tratado sobre heranças que o corpo carrega, que encontrou sua melhor poética. (KATZ, 2008a)

LinhaGens (2009) fricciona a linhagem russa de $A$ morte do cisne com a obra $O$ Silêncio dos Pássaros, criada por minha mãe (com o Grupo Pró-Posição) nos anos 1970.

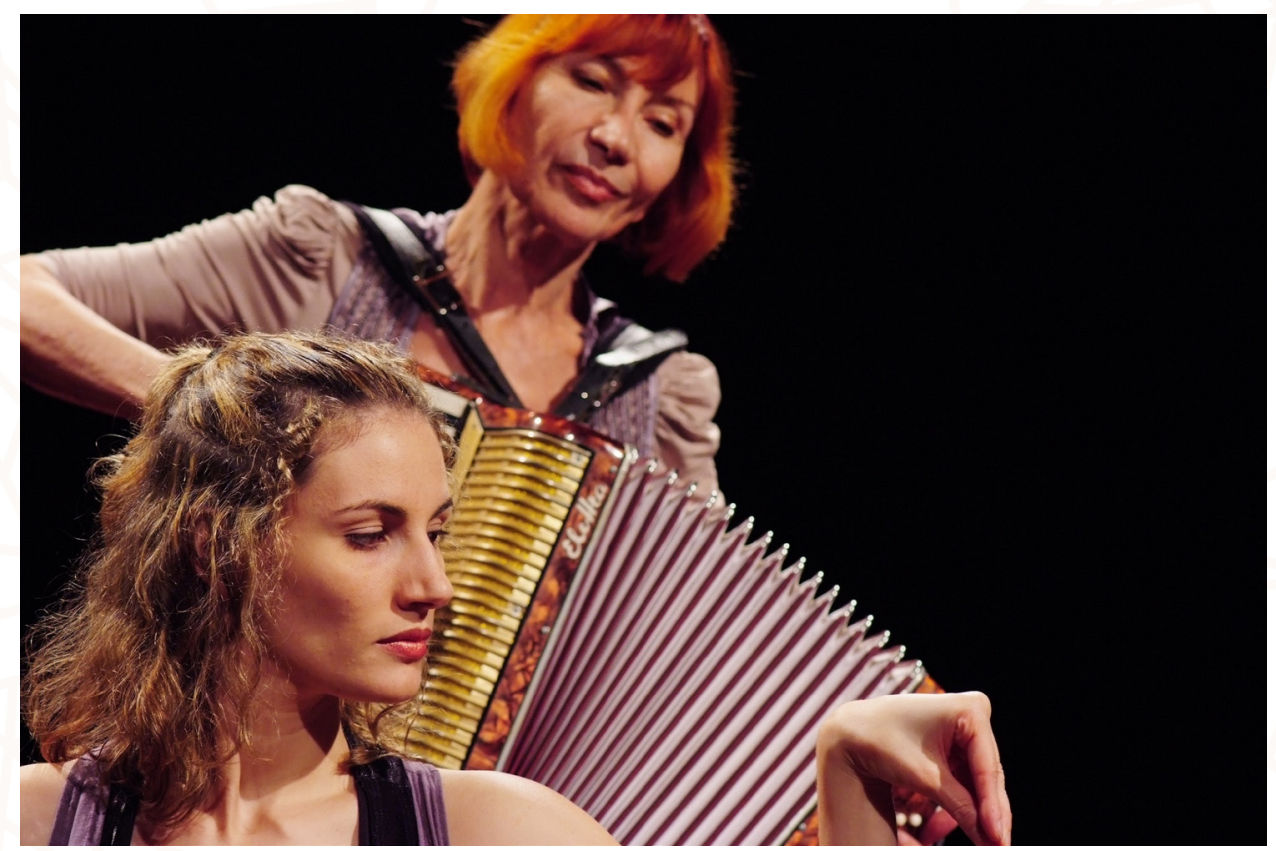

Figura 3 - Andréia Nhur e Janice Vieira em LinhaGens (2009).

Foto: Lenise Pinheiro.

O cisne enunciado pelo Pró-Posição é um eco do legado que a obra de Fokine-Pavlova passou a significar: a morte da bela ave, porta-estandarte da dança clássica, era ao mesmo tempo o fim e a continuidade da tradição. Mas a formulação cênica das obras da Trilogia destrona o cisne como legado que persiste como símbolo universalizante da dança, tratando-o como um resto memorial impactado por corpos singulares. A citação entre obras não é mera reinvenção de passos em torno de uma estrutura magna, mas uma conversa entre corpos-testemunhos das histórias da dança. 
A ideia de testemunho que propomos aqui emerge das discussões trazidas pelo filósofo Giorgio Agamben, no final da década de 1990, em sua reflexão sobre a defasagem que compõe a própria estrutura do testemunho. Agamben (2008) defende que o testemunho relata o que está em falta na linguagem, já que é composto pelas reminiscências de um fato.

Segundo o autor, para testemunhar é preciso ter a experiência, mas ao se ter a experiência, não se pode mais narrar. Então, o que é possível testemunhar, sem que se tenha vivido a experiência em sua completude? Seria o relato uma invenção? Para Agamben, dar testemunho seria ocupar a lacuna deixada por aquele que poderia, de fato, testemunhar, ou seja, testemunho é o próprio sujeito anunciando sua impossibilidade de falar:

Assim como, no céu estrelado visto à noite, as estrelas resplandecem circundadas por uma densa treva, o que, na opinião dos cosmólogos, nada mais é do que o testemunho do tempo no qual elas ainda não brilhavam, assim também a palavra da testemunha dá testemunho do tempo em que ela ainda não era humana. (AGAMBEN, 2008, p. 161)

Sob essa condição fugidia, podemos olhar para algumas experiências em dança e vislumbrá-las como historiografias dançadas, uma vez que seus corpos relatam - na impossibilidade de reencenar os gestos - aquilo que lhes é possível no trato com a história. História essa composta de memórias, em que tudo poderia se qualificar como resto:

Eles [os processos históricos] não têm um fim, mas um resto; não há, dentro deles ou debaixo deles, um fundamento, mas, entre eles, em seu meio, há uma separação irredutível, na qual cada termo pode pôr-se em posição de resto, pode testemunhar. (AGAMBEN, 2008, p. 158)

O voo do cisne pelas histórias da dança - assim mesmo, no plural traz à reflexão a presença desse corpo-testemunho que conta o passado da dança nos termos do gesto presente. Sempre atualizado nos mais distintos corpos, sua invocação persiste e se dissipa, testemunhando que a dança conta mais sobre sua história do que qualquer escritura histórica poderia ensejar. 


\section{Referências bibliográficas}

AGAMBEN, G. O que resta de Auchwitz: o arquivo e a testemunha. São Paulo: Boitempo, 2008. (Homo Sacer, III).

BOISSEAU, R. Panorama de la danse contemporaine. Paris: Textuel, 2008.

BREMSER, M. (Ed.). International dictionary of ballet. Detroit: St. James Press, 1993. $2 \mathrm{~V}$.

CAMARGO, A. V. A. Cartografias midiáticas: o corpomídia na construção da memória da dança. 2012. 205 f. Tese (Doutorado em Comunicação e Semiótica) - Pontifícia Universidade Católica de São Paulo, São Paulo, 2012.

COHEN, S. J. Next week, Swan Lake: reflections on dance and dances. Middletown: Wesleyan University Press, 1982.

(Ed.). The International Encyclopedia of Dance. Oxford: Oxford University Press, 1998.

FRANKO, M. The work of dance: labor, movement, and identity in the 1930s. Middletown: Wesleyan University Press, 2002.

GINOT, I.; MICHEL, M. La danse au XXe siècle. Paris: Larousse, 2008.

GREINER, C. O Corpo: pista para estudos indisciplinares. São Paulo: Annablume, 2005.

KATZ, H. Mostra nasce apostando nos novos. O Estado de S. Paulo, São Paulo, 19 nov. 2008a. Cultura.

O papel do corpo na transformação da política em biopolítica. Revista Trama Indisciplinar, São Paulo, v. 1, n. 2, p. 18-27, 2010.

Por uma teoria crítica do corpo. In: OLIVEIRA, A. C.; CASTILHO, K. (Orgs.). Corpo e moda: por uma compreensão do contemporâneo. Barueri: Estação das Letras e Cores, 2008b. p. 69-74.

. Um, Dois, Três: a dança é o pensamento do corpo. Belo Horizonte: FID, 2005.

LAUNAY, I. A elaboração da memória na dança contemporânea e a arte da citação. Dança, Salvador, v. 2, n. 1, p. 87-100, 2013.

À la recherche d'une danse moderne: Rudolf Laban et Mary Wigman. Paris: Chiron, 1996.

Poétiques de la citation en danse: d'un faune (éclats) du Quatuor Albrecht Knust, avant-après 2000. In: LAUNAY, I.; PAGÈS, S. Mémoires et Histoire en Danse. Paris: L'Harmattan, 2010. p. 23-72.

LE MOAL, P. (Ed.). Dictionnaire de La Danse. Paris: Larousse, 2008.

LíVIO, A. Béjart. Paris: Age d'homme, 2004.

LOT, C. La mort du cygne de Michel Fokine, enjeux et devenirs d'un ballet "presque improvisé”. 2007. Dissertação (Mestrado em Dança) - Université de Paris 8, Paris, 2007. 
MONEY, K. Anna Pavlova, her life and art. New York: Alfred A. Knopf, 1982.

ROSSÉ, B. Le Cygne. Toulouse: Art Line, 2000.

TESTA, A. 100 grands ballets: un choix extrait du répertoire choreutique. Rome:

Gremese, 2008a.

Les grands ballets: repertoire de cinqu siècles de danse. Rome: Gremese, $2008 \mathrm{~b}$.

Recebido em 01/08/2016

Aprovado em 04/11/2016

Publicado em 21/12/2016 